\title{
Training for my Life: Lived Experiences of Dislocated Workers in an Advanced Manufacturing Training Program
}

\author{
Marquita R. Walker
}

\begin{abstract}
This qualitative paper explores the lived experiences of one group of workers dislocated because of globalized trade policies who completed a hybrid Advanced Manufacturing Training Program (AMTP) by taking advantage of Trade Adjustment Assistance (TAA), a federally-funded program for retraining workers dislocated because of trade policies. The research questions focus on how satisfied these workers are with the services and programs provided by TAA. Focus groups and survey instrument results indicate these workers found TAA services and processes cumbersome and timeconsuming and actually had the effect of discouraging their education, training, and selfemployment. The consequences of their dislocation as it relates to TAA experiences are increased frustration and dissatisfaction with the TAA program. Serious consideration for TAA policy changes should be deemed of utmost importance.
\end{abstract}

Keywords: Advanced manufacturing training, dislocated workers, lived experiences

\section{INTRODUCTION}

Globalization has created an environment in which American firms seek to lower labor costs by moving production offshore, forcing American workers to compete for work with workers worldwide. US government free trade policies, which promote this competitiveness, offer to American workers dislocated by trade policies opportunities for retraining through federally-funded Trade Adjustment Assistance (TAA), a training program which provides 104 weeks of paid training for workers certified as dislocated because of import competition. This paper explores factors which impacted thirteen displaced workers from the Navistar Engine Plant and Foundry in Indianapolis, Indiana. The thirteen workers were certified to participate in TAA. Through a focus group, their satisfaction with the TAA program and services from workforce dislocation to workforce reintegration is measured. Their stories reflect one local solution to the global problem of import competition.

\section{BRIEF HISTORY OF WORKER DISLOCATION}

Periods of worker dislocation continue to increase especially during times of economic downturns. Dislocated and displaced workers are defined as "persons 20 years of age and older who lost or left jobs because their plant or company closed or moved, there was insufficient work for them to do, or their position or shift was abolished" (Bureau of Labor Statistics, 2010a). Long tenured displaced workers are those who have worked at least three years with a firm. Dislocated workers lost 51 percent of their jobs following the 1973-1975 recession, 64 percent of their jobs following the 1981-82 recession, and 85 percent of their jobs following the 1990-92 recession (Koppel \& Hoffman, 1996, p. 114). Continued production cutbacks due to increased off-shoring and

Marquita R. Walker, Ph.D., is an Assistant Professor of Labor Studies in the Indiana University School of Social Work at the Indiana University-Purdue University Indianapolis campus.

Copyright (C) 2012 Advances in Social Work Vol. 13 No. 2 (Summer 2012), 262-278 
outsourcing estimated around "two million permanently displaced workers" (Beneria \& Santiago, 2001, p. 78) by 1997. In 2010, the number of permanently displaced and dislocated workers in the United States was 6.9 million (Bureau of Labor Statistics, 2010b).

During the time of economic expansion from 1993 to 1994, sometimes called the "New Economy," many workers were still displaced through plant closings and layoffs (Knapp \& Harms, 2002). (Hipple, 1997) posited that during this period over "2.4 million displaced workers reported they had lost their jobs because their plant or company had closed down or moved" and another "one-fourth cited 'slack work' as the reason for their job loss" (Hipple, 1997). Three in ten workers reported their "individual position or entire shift had been abolished (Hipple, 1997).

A more current analysis of displaced workers suggested their plight had not improved. According to the Bureau of Labor Statistics (2011), the number of long-term unemployed workers who have remained jobless for 27 weeks or more is 5.8 million while involuntary part time workers numbered 8.6 million. Involuntary part-time workers experienced reduced hours and were unable to find full time work. There were 2.5 million marginally attached or discouraged workers available for work and not currently looking for work because they believed no work existed.

The Bureau of Labor Statistics divided the U.S. into geographic regions for purposes of reporting job loss. The East North Central region in which Indiana is located had the second highest job loss of any US region losing 1,268,000 jobs as of January, 2010 (Bureau of Labor Statistics, 2010c). Manufacturing workers in this region who produced durable goods lost 328,000 jobs during this period (Bureau of Labor Statistics, 2010c). Indiana manufacturing employment contracted by 25 percent from June 2006 to December 2009 (Joint Economic Committee, 2010b, p. 8).

Indiana relied on manufacturing for " $19 \%$ of all employment” (Joint Economic Committee, 2010a, p. 5). Most of these manufacturing jobs were in durable goods such as "transportation equipment, machinery, fabricated metal products, and primary metals" (Joint Economic Committee, 2010a, p. 1). Indiana's reduction in jobs in durable manufacturing contributed to the national durable manufacturing job loss of "two millions jobs between June 2006 and December 2009” (Joint Economic Committee, 2010a, p. 6).

The increase or reduction in orders for durable goods is an economic indicator of whether the overall economy is growing or shrinking. In Indiana since December 2009, there is some growth in durable goods manufacturing from restocking inventories but not new orders. A subsector of durable goods, transportation equipment, has seen 22,000 jobs added between December 2009 and December 2010 (Joint Economic Committee, 2010a, p. 10). Most firms' inventories reached pre-recession levels around January 2010 so new growth came from export-related demand with "over one-third (35.9 percent) of all jobs supported by exports in the manufacturing sector" (Joint Economic Committee, 2010a, p. 14). 


\section{Decision of Dislocated Workers to Participate in Training Programs}

Based on the theory of human capital in which individuals invest in skills and knowledge so the value of their labor produces economic gains, dislocated workers make choices to participate in training programs based on the program's "impact on future earnings, time remaining in the trainees' work lives, and direct and indirect costs of going to school” (Jacobson, LaLonde, \& Sullivan, 1993, p. 51). Older displaced workers have fewer years remaining in the workforce, so they have less incentive to enroll in training programs than do younger workers (Heckman, Lalonde, \& Smith, 1999; Jacobson, 1993; Knapp \& Harms, 2002).

Participation in government subsidized programs depends on individual motive. If we study the reasons displaced workers take advantage of these programs, and then explore displaced workers' perceptions of the ease or difficulty of accessing the programs, and their perceptions of the effectiveness of these programs, then stakeholders can better understand how to fashion polices which deliver better payoffs for their investments.

\section{Why Workers Become Displaced}

Workers may lose their jobs for many reasons: changes in technology, plant or company closures, insufficient work, changes in demand for goods and services, inept management, economic downturns, or for some other reason (Bureau of Labor Statistics, 2010c). There is little scholarship concerning exactly why workers are displaced, but there is growing evidence that workers do lose their jobs because of import competition (Addison \& Fox, 1995; Kletzer, 1998).

Such is the case with over 1650 workers at the Navistar Engine Plant and Foundry in Indianapolis, Indiana. Over the last six years, all Navistar workers, represented by the United Auto Workers (UAW) Locals 98 and 226 have become dislocated through import competition thus making them eligible candidates for Trade Adjustment Assistance, a federally funded program to retrain workers who have lost their jobs due to import competition. During 2009, Locals 98 and 226 applied for certification through Workforce Development for the final group of employees who received layoff notice, and certification was granted. Some of these dislocated employees then begin to complete and file the necessary paperwork to comply with TAA requirements to receive educational monies.

The training programs eligible for TAA assistance have to be on an approved statewide occupational training provider list in order to receive monies from TAA. Educational providers must submit an application to Indianapolis Private Industry Council (IPIC), Indiana Department of Workforce Development (DWD), and demonstrate successful training and placement in high-demand occupations. Approval comes from DWD.

\section{Economic Rationale for Subsidizing Dislocated Workers}

Job loss is costly not only to the worker but to society. Joblessness costs society because fewer workers are contributing to the tax pool from which the government 
operates. When tax coffers are empty, fewer monies are available for operational expenses, and fewer social welfare programs can operate. Therefore, governments have an incentive to discourage joblessness by initiating training programs to reintegrate workers back into the workforce. Another reason to subsidize dislocated workers is to provide more skilled workers in order to alleviate shortages of workers in certain arenas and to minimize poverty by increasing the earning power of low income workers (Ashenfelter, 1978). Joblessness is also costly in terms of decreased output and productivity and increased incidence of physical and mental health problems, financial problems, and crime (LaLonde, 2003).

\section{Social Rationale for Subsidizing Workers}

When workers are displaced, they suffer from lost income streams and lost economic rents as well as losses during the adjustment period (Leigh, 1995). According to LaLonde (2003) joblessness creates or increases the incidence of "substance abuse, crime, and broken homes, as well as costs associated with the loss of individuals' self-esteem that is thought to come from work" (LaLonde, 2003). A social cost of displacement also occurs when powerful interest groups block socially beneficial programs such as free trade policies and new labor saving technology.

\section{Government Response to Dislocated Workers}

To increase jobs in a still fragile economy, the states need targeted policies to bring manufacturing jobs to Indiana and ensure there are skilled workers to fill those jobs. Toward this end, Congress and the Obama Administration passed The American Recovery and Reinvestment Act of 2010 which channeled "\$ 1,250,000,000 for grants to the states for dislocated workers employment and training activities" (American Recovery and Reinvestment Act, 2009).

This increased funding provided money for the creation and delivery of new educational programs which met the requirements of TAA; all course content delivered by training providers must include theoretical and practical instruction which would prepare workers to secure future "green" or technical jobs as outlined by the Employment and Training Administration, Department of Labor. A joint effort by Navistar management and UAW Locals 98 and 226 created such a program for dislocated workers from the Navistar facility who were certified for TAA benefits. The bulk of the training program, which would revolve around practical and hands-on application in manufacturing, was delivered by a local community college. Higher level thinking skills, team development, and problem-solving courses were delivered by a research university, and lean manufacturing courses known as Six Sigma were delivered by a technological institution. This hybrid training program met the requirements of and was approved by IPIC and DWD and paid for with TAA monies.

\section{Firms’ Response to Dislocated Workers}

Firms are often hesitant to tell workers about impending reductions in workforce for several reasons: (1) the firm doesn't want the community to know it is downsizing for 
fear of consumers seeking other vendors; (2) the firm does not want its workers to look for work elsewhere while still employed with them (Casey, Miller, \& Johnson, 1997); (3) the firm fears equipment and property might be damaged (Bray, 2002).

\section{Who Participates in the Programs?}

Most of the literature concerning TAA training programs looks at the economic impact of training dislocated workers to reintegrate into the workforce. Decker and Corson (1995) examined "the pre-layoff characteristics and post-layoff labor market experiences of two nationally representative samples of TAA program participants” (p. 758) with the objective of identifying the types of workers who utilize TAA training and to determine the benefits participants receive. They reported findings that the TAA program training did not have a significant positive impact on the earnings of the participants "at least in the first three years after the initial Unemployment Insurance claim” (p. 773). Their comparison of two samples of dislocated workers, pre- and post1988, reflect dislocated workers experienced significant wage losses after being laid off, and those who were reemployed earned less than in their previous job.

Jacobson, LaLonde, and Sullivan (1993) studied 65,000 workers displaced from the aerospace and wood product industries in the state of Washington between 1990 and 1994. Of the fifteen percent of dislocated workers who attend retraining programs, the younger participants tended to be white, displaced from the aerospace industry, and better educated. Older participants tended to be from the wood products industry. Participants who attended training programs were found to have "lower than expected earnings relative to comparably educated non-trainees” (p. 53). Thus, the participants who attended training programs are not representative of the broader sample of dislocated workers.

Another study conducted by Jacobson, LaLonde, and Sullivan (2005) looked at the returns to retraining displaced workers over the age of 35 using the same data from Washington State in the 1990s. Younger workers' and older workers' earnings after community college training are compared. Though fewer older workers participate in community college classes, both groups' "quarterly earnings [are] similar” (p. 398) and "retraining seems likely to have been a sound investment" (p. 409). They conclude that older workers "acquire new skills about as effectively as do younger workers" (p. 406) but the social net benefits, though still positive, are less robust because "community college schooling is heavily subsidized by taxpayers” (p. 409).

\section{HISTORY OF NAVISTAR}

Navistar, a premier manufacturing facility on Indianapolis's east side, formerly known as International Harvester, employed nearly 2, 000 workers in its facility, which consisted of an engine plant and a metal casting foundry, in the 1990s. The engine plant produced diesel engines for Ford Motor Company, their primary customer, while the foundry, owned by Navistar and known as the International Casting Corporation (ICC), produced metal castings for diesel engines for Ford and other customers as well. The nationwide decline in manufacturing affected the Navistar plant's workforce, and by 
2005, the plant employed around 1,100 workers in the engine plant and 550 workers in the foundry.

In 2007, the Ford Motor Company sued the Navistar plant for raising its products' prices without explanation and not sharing in the warranty cost on its engines. The dispute was resolved when Ford decided to make its own diesel engines in Mexico. As the country slumped into an economic recession, the demand for pickup trucks nosedived, and in May, 2008, "Navistar laid off 500 assembly workers because of low demand” (McLaughlin, 2009).

In January, 2009, Navistar International Corporation, based in Warrenville, Illinois announced the closure of the Navistar east side 1.1 million square foot engine plant and foundry by the end of 2009. Previously contracted through 2012, Navistar began winding down operations but continued to produce diesel engines for Ford through 2009. Navistar worked with the automaker on a number of projects including two existing joint ventures which expanded operations into China and India and an engine-supply agreement in South America in an effort to diversify its product offering (McLaughlin, 2009). Ford and Navistar agreed to end their contract on December 31, 2009.

The engine plant closed in December, 2009, but the ICC foundry found a way to maintain its existence without the 73 year relationship with Ford because it produced engine blocks for other customers. This allowed a delay of the foundry's closing.

In April, 2010, Navistar International set the anticipated closing date for its Indianapolis iron foundry for July 16, 2010 at which time 220 employees lost their jobs. Worker Adjustment and Retraining Notification (WARN) notices about the foundry's closing were filed with Indiana's Department of Workforce Development. Scheduled layoffs included a total of 176 workers on July 2 and 24 workers on July 16 (IBJ Staff, 2010, April 28). This meant the remaining workers in the plant were notified of impending layoffs.

Worried about their jobs, these workers looked to their union for information. The business agent for UAW Local 98 was instrumental in helping them maneuver through these difficult times. Local 98 became command central for these dislocated workers who needed to know their contractual rights during lay-offs and plant closings as well as options available to them for assistance from Navistar, the UAW, and the government.

The business agent was active in securing Andre Carson, Congressman for Indiana's 7th district, to intervene with WorkOne, the state's one-stop career center, on behalf of the dislocated Navistar workers; the business agent and the Congressman met with and informed these union members in January, 2010 of their eligibility for TAA assistance.

About 3-4 months before being laid-off, the business agent encouraged them to enroll in the newly developed hybrid Advanced Manufacturing Program. At that time there were around 150-300 laid-off workers eligible for TAA. About 40 of these workers took the HVAC heating and air, welding, or electrical tracks while others opted for training in heavy equipment maintenance. Forty workers opted for the AMTP. Other workers chose not to take advantage of TAA assistance. 
In order to qualify for the AMTP, workers had to test out of basic math and reading requirements at a ninth grade three-month level. Those opting for the AMTP who tested below that standard had to complete basic education classes that were held at Local 98's union hall.

In an effort to assist both dislocated Navistar management and union workers, Navistar and the UAW worked together in providing assistance by installing a bank of computers at Local 98's union hall in order for all dislocated Navistar workers to file TAA paperwork and work on adult basic education classes. This in-house joint effort grew from the necessity of providing services to a growing crowd of dislocated workers in a field already crowded with thousands of dislocated workers. Mornings at the union hall are devoted to Adult Basic Education classes while afternoons are left open for filing paperwork.

In order to qualify for TAA, workers had to be dislocated from their jobs because of import competition and file a group certification petition with the TAA and be certified (America), file an individual TAA application through the WorkOne career center, meet several deadlines, submit all required forms in a timely fashion, and enroll in an approved trainer program. Because of the huge numbers of dislocated workers flocking to WorkOne centers to file for unemployment benefits and file TAA paperwork, Navistar and the UAW were instrumental in bringing a satellite WorkOne office to Local 98's union hall. Staffed with unemployment personnel and one TAA coordinator, this local office alleviated some strain on Navistar workers who would otherwise have to travel to a WorkOne center and wait in congested lines for services.

Because of the huge number of individual TAA applications being processed through the WorkOne centers, the [TAA] coordinators and WorkOne centers were overwhelmed by applications, so the process took longer than usual. According to the AFL-CIO Working for America Institute (2001), the vast majority of TAA petitions had long processing times. The TAA legislation required an investigative period of 40 days (Employment and Training Administration Services Act, 2002), but from January 1, 2009 to March 1, 2011, the national average processing time was over 102 days. This elongated processing time had a deleterious impact on workers who are unable to utilize their full benefits under TAA until approval, were delayed in beginning their training programs, and adversely suffered from decreased morale.

The UAW, which represented the Navistar workers, negotiated several packages for workers laid off in 2008 and those affected by the engine plant's closing. In 2009, Navistar offered to continue the foundry's operation if UAW Local 226 agrees to a reduced wage and benefit package. Navistar reported it needed reductions to remain cost competitive in the market. A ratification vote for this contract was rejected by Local 226 members on August 17, 2009.

On July 15, 2010, Navistar and UAW Local 226 negotiated and accepted by a 58\% majority a new five-year contract covering 250 workers that included wage and benefit reductions. The new contract that extended through July, 2015 reduced vacation time, holidays and wages, and included a buy-out for older workers. The new pay structure was $\$ 17$ per hour for production jobs and \$23 for skilled trades and technical positions (IBJ 
Staff, 2010, April 28).Though the foundry continued to be operational; there was a four to six month shutdown while Navistar expended it backlog of parts.

In April, 2011, PurePOWER Technologies (PPT), LLC, based in Columbia, South Carolina and which produced diesel power systems, emissions control systems, and industrial metal castings announced it would take over the Navistar foundry and produce diesel structure components. This move resulted in recalling 120 dislocated workers from the foundry with plans to recall 30 more by June, 2011. Long term plans included a \$19 million dollar investment in the firm and hiring 100 more workers by 2014 (Todd, 2011). Workers were recalled according to seniority beginning in June, 2011. The companies also continued to collaborate on a range of initiatives, including their existing Blue Diamond Truck and Parts joint ventures and their diesel engine supply agreement in South America.

The future of the Navistar/PPT has currently been somewhat stabilized by the forgiveness of a debt owed to the city in 2010. PPT applied for and received a five million dollar personal property tax abatement from the Metropolitan Development Commission (MDC). Recognizing the casting facility acted in good faith during a severe economic downturn as the reason for nonpayment, the city's MDC restructured the debt in anticipation of future investment by the facility (Olson, 2011).

\section{METHODOLOGY}

Institutional Review Board approval was granted for this study prior to data collection. Data collection included returned survey responses and focus group participation. Utilizing convenience sampling, ${ }^{1} 14$ students enrolled in the hybrid AMTP offered in fall, 2010 were mailed requests for participation and consent forms during summer, 2010. Thirteen students initially agreed to take part in the study that involved completing a survey instrument which asked for demographic information and requested their participation in a focus group. One student opted out of the program very early. Eleven students returned the survey and 5 participated in the focus group. Survey results denoted demographic data that consists of age, gender, length of service at Navistar, years of education, and consent to participate in a focus group.

Table 1: Demographic Survey Data for Dislocated Worker Participants from Navistar

\begin{tabular}{cccccc}
\hline $\begin{array}{c}\text { Number of } \\
\text { returned surveys }\end{array}$ & $\begin{array}{c}\text { Average age of } \\
\text { participants }\end{array}$ & Gender & $\begin{array}{c}\text { Average tenure } \\
\text { at Navistar }\end{array}$ & $\begin{array}{c}\text { Average years } \\
\text { of education }\end{array}$ & $\begin{array}{c}\text { Participate in } \\
\text { focus group }\end{array}$ \\
\hline 11 & 45 years & Male: 7 & 11 years & 11 & 5 \\
& Female: 4 & & \\
\hline
\end{tabular}

\footnotetext{
${ }^{1}$ The use of convenience sampling does not ensure the small number of participants is a representative sample of dislocated workers from the Navistar plant.
} 
The focus group met with the PI at a local restaurant to discuss their history with Navistar and their involvement with TAA. The focus group met for two hours during which responses from participants were recorded via notes taken by the PI. These notes became the basis for the data analysis. The following questions were asked during the focus group:

1. Please tell me about your experience after you found out your job/position was going to be eliminated.

2. Tell me about your experiences in filing for and receiving training assistance through the TAA.

3. Tell me about your experiences in taking the AMTP.

4. Tell me about your experiences in securing future employment as a result of receiving certification in Advanced Manufacturing Training.

A hand analysis of the qualitative responses utilizing lean coding (Creswell, 2009) resulted in three themes reflecting the lived experiences of students' satisfaction with the services and programs provided by the TAA. These themes evolved from participants' concern and apprehension, discouragement, disillusionment, disorganization, and uncertainty concerning the application process, the structure and organization of the program, and the outcomes of the program.

\section{DISCUSSION}

All thirteen dislocated workers participating in this study were members of UAW and had lifetime recall rights. Prior to layoff, they each made around \$21.50 per hour and had good benefits. They had an excellent 90/30 insurance plan, a cost of living allowance (COLA), a night shift differential, and four weeks of vacation pay after ten years of service. They each participated in the company's $401 \mathrm{k}$ with a $6 \%$ company contribution match. Uniforms and corresponding laundry service were provided to them every two weeks at a cost of \$6 per week. Optional overtime was available to them from 19992006. After 2006, overtime became scarce, and they each worked only eight hours per day Monday through Friday.

After they were laid off from Navistar, they drew state unemployment benefits as well as supplemental unemployment pay, a contractual benefit. At the time the focus group was conducted, all had been certified for TAA assistance, engaged with the TAA process, and were nearing completion of their AMTP.

Three themes relating to participants' satisfaction with TAA services and its programs emerged from interpretation of participants' responses: 1) processes involving certification and application to the TAA program; 2) the structure and organization of the AMTP; and 3) outcomes from the AMTP. The negativity associated with participants' lived experiences as told through their narratives suggests an overall dissatisfaction and disillusionment with the TAA process and the AMTP. The first theme involved the processes in which participants engaged after learning of the plant closure, their 
subsequent dislocation, application for TAA certification and training and engagement with the training program.

\section{Processes Related to Certification and Application to the TAA Program}

The first finding suggested workers were concerned and apprehensive about the processes related to certification and application to the TAA program. In response to focus group question one which asked workers to tell about their experiences after they found their jobs/positions was going to be eliminated and question two which asked workers about experiences in filing for and receiving training assistance through the TAA, workers confirmed their concern and apprehension about upcoming layoffs, who to turn to for help, where to go to get information, and how to apply for TAA assistance. Participants recount: "About nine months prior to being laid off, we were notified we were going to be laid off" and "There were rumors going around the plant that the facility was closing, but we couldn't get a straight answer from Navistar management. Navistar stalled about work going out of country.” The uncertainty associated with not knowing management's future plans was complicated by the difficulty in applying for TAA assistance. Once certified for TAA assistance, which was facilitated by Navistar management and the UAW locals, the process of actually qualifying for training monies began.

Participants were discouraged and frustrated by the many TAA requirements administered by WorkOne in order to qualify for assistance. One participant reported, "We filled out lots of forms. One form asked questions like: how will you support yourself during the time you are in school? What contingency plans have you made to pay your bills?” Another participant said:

We had to take adult basic education classes before signing up for TAA. We had to pass math and reading tests. There were probably about 40 people interested in taking the Advanced Manufacturing Track. We would meet at Local 98's hall where there were computers and work on filling out the TAA forms. The business agent was a great help to us. He encouraged us all the way. We would not have been able to complete the paperwork if it were not for him.

The number of forms and upcoming deadlines seemed overwhelming to these participants and contributed to their sense of disillusionment about the necessity and value of completing a training program.

Each participant met with a TAA coordinator in order to receive the necessary forms and apply for training. One participant reported he was discouraged from applying for training from an approved TAA educational provider by the TAA coordinator with whom he worked even though he was approved for TAA assistance. He related the TAA coordinator discouraged his application because "she didn't think I was smart enough to complete the program and that I would fail." He said the process of getting approved for TAA was difficult enough without having to deal with coordinators who tried to discourage application for training in which you were interested. So this participant entered the AMTP instead of a program he preferred. This account reflected some issues with TAA coordinators in general. In talking with several TAA coordinators, they 
reported no training or experience in dealing with TAA legislation and processes. One TAA coordinator said:

One day I was working in the unemployment office, and the next day I was transferred to another department and became a TAA coordinator. I was given no training. There isn't even a handbook for the coordinators. I was lost.

This type of employee transfer between various state departments suggested some of the confusion and disruption during the time the Navistar dislocated workers were applying for TAA assistance could have been reduced or eliminated had trained staff been available to handle the applications. The subjective nature of a determination of "how smart" a dislocated worker might be made by an untrained TAA coordinator could have a negative impact on the worker who is already distraught about his/her future. The dislocated worker, already determined to be eligible for approved provider training, now had to adjust his/her plans to enter a program that was not his or her first choice.

Engaging with the TAA coordinator on site at Local 98, the study participants reported the TAA coordinator explained the process, deadlines, and forms to them. One participant reported:

She told us we had to talk to/contact at least three other people in a field we thought we might want to enter and interview them. We really didn't know what questions to ask them though. It was hard to find these people.

The confusion these workers felt during this process was obvious. Full of frustration over the operation of the process, it was clear the workers felt adrift without a life raft. Each participant felt helpless in finding employers to interview and knowing what questions to ask them. Another participant described this as "phone booking." He said he would just open the phone book and find some name associated with some manufacturing facility and call them and ask them if he could interview him or her. Some of them talk to him; some of them do not. One very frustrated participant responded:

The TAA agents' advice was terrible. I was so frustrated; I went home and threw the papers down. I said I wasn't going to go through all that to go to school. The TAA program discourages workers who want to get an education. I was discouraged because I had to write an essay, contact 3 colleges I might be interested in going to, find out the cost, and interview people in the field in which I was interested. I did a lot of phone booking; trying to find workers to interview was a problem. I was given a questionnaire and the interviewee had to respond. The requirement was to turn in 3 interviews. The essay was about you; why should you be allowed to get TAA assistance. You had to report that you had looked and couldn't find a job and how was I going to support myself until school was completed. The deadline for submission was only two weeks. The entire packet had to be completed and submitted which included a resume.

The excessive numbers of forms and deadlines to complete, file, and comply with TAA guidelines posed a challenge to dislocated workers. This cumbersome process did not 
contribute to the overall wellbeing of dislocated workers and discouraged them from availing themselves of TAA assistance.

\section{Structure and Organization of the AMTP}

The second finding suggested participants were discouraged and frustrated with the structure and organization of the AMTP. Participants' narratives about their experiences in taking the AMTP reflect discouragement and frustration with the content, timing, delivery, and instruction of the bulk of the program.

Participants began taking classes in the AMTP in May 2010. One participant said, "The curriculum presented to us by the community college, the technological university, and the research university looked good, and we were encouraged by the business agent and others to move forward with the classes.” Initially the classes were held by the community college from 1-4 pm, Monday through Thursday at Local 98's union hall. Limited hours at the hall were available because Adult Basic Education classes for dislocated workers upgrading their basic skills in order to qualify for TAA training were being held there during the morning hours. From the start, these limited training hours prolong the length of the training program. Two month's into the program, Local 98's union hall was sold, so the community college classes move about two blocks away to UAW Local 226's union hall. This move introduced uncertainty into the training program because the workers were never sure where they were going to meet. Communication from the community college was sparse and untimely. Workers might show up for a scheduled class only to find the class was cancelled or moved without notification. There were no textbooks provided to the students and little communication between the instructors and the workers. The workers regretted their enrollment in the program. One participant reported:

The curriculum looked good, but there was no consistency in the program. Students never know in advance where their classes are to be held, when they are to attend, who their instructors are, and we have received no/few books concerning their instruction. Computers are limited, so we often have to share a computer. Many of the instructors are not knowledgeable about the classes they are teaching, and there is no feedback concerning students' tests or grades. The community college program coordinator told us that employers want workers with critical thinking skills, math, computer skills, etc., but we are not getting that kind of training in this.

Another participant said:

The program fell apart because of inconsistency with classes. The community college could not provide instructors who were knowledge[able] about the specifics of the courses. For instance, an instructor who was a (retired) math teacher was pulled in to teach Intro to Manufacturing.

Yet, another participant explained, "I feel we were pushed to fast without the time to learn. We have all been pushed through and get out of our lives. I feel we were being 
rushed, pushed, to get us out of their lives.” The depth of frustration resounded in this participant's statement:

[The community college] rushed me through, so I feel I'm a bad product. I'm supposed to represent [the community college] and I'm a failure. What's that all about? We would like to see the program be a success and not a failure.

Reiterating this frustration, another participant said:

I wished I could have gone into heavy equipment operator, a four month class, instead of this. At least I would have been done by now. I think the program is a failure.

All participants responded they were satisfied with the instruction provided by the technological and research universities' curriculum. Those pieces of the training program, which totaled five weeks of instruction, were provided by trained professionals who supplied books and material and delivered quality instruction in a timely fashion in adequate facilities. There were no negative comments about those pieces of the training program.

The general sentiment reflected from participants' narratives was their frustration with the community college's content and delivery of the program complicated by their discontent with continually filling out forms and meeting deadlines to comply with TAA requirements. Noncompliance with TAA requirements meant dismissal from the program and termination of all future TAA benefits so participants always felt pressured to comply for fear of losing future training monies. This created an environment in which participants felt they were set up for failure because of the inappropriateness of the training content and delivery coupled with the TAA requirements to complete and verify components of training by certain deadlines.

\section{Outcomes from the TAA Program}

The third finding reflects participants' satisfaction, actually their dissatisfaction, with the outcomes associated with the training program such as securing employment and maintaining their living standards.

The participants in the AMTP completed the program in July, 2011. What began as a 10-month program evolved into a 14-month program. The 13 students finishing the program received certification in 10 areas of Advanced Manufacturing which should have given them an advantage in the job market. Disillusioned and frustrated with the length of time it took to finish the program and the disorganization of the community college's training, these participants hoped they would be recalled to the Navistar/PPT foundry because they saw little prospect for work in Advanced Manufacturing elsewhere. One participant explained:

I go in once a month and talk to the TAA counselor. I tell her I'm dissatisfied. I don't know what she does with that information. I don't think anyone in our class has the confidence to go out and get a job. 
Another participant said:

If called back to the factory, the [advanced manufacturing] training ends. Then on the job training begins when we go back to work. The company pays for that.

Participants' narratives suggested a general dissatisfaction with their overall training and the likelihood they would find work at comparable or higher wages after the training was completed. There was also dissatisfaction about the certifications they received. Their general criticism was that the cost of their program was comparable to the cost of a degree program from an accredited college; they felt their efforts and energies would have been better spent in applying for acceptance to an accredited institution of higher learning and completing a terminal degree. This was not an option for them at the time of their layoffs because the time frame to complete a degree would have been elongated thus delaying their reentry into the workforce, and they would have to be accepted to an institution of higher learning with a certain level of credentials they did not have.

As of this writing, several of the workers in the AMTP have been recalled to work at Navistar/PPT, and several more are planning to return soon. They are thankful to be returning to work even though they will have a reduced wage and benefit package. One participant mentioned the uncertainty of the future:

If they [Navistar/PPT] call us back, and they lay us off again, our insurance runs out. We had one year of insurance [under the old contract], and we had life time recall rights. The new contract is for five years.

The lived experiences of these dislocated workers from dislocation to reintegration into the workforce and the adjustment of their living standards to new wage and benefits packages suggested training programs currently available need revision to better meet the training needs of dislocated workers and potential employers. Further research into restructuring TAA policies is necessary.

\section{CONCLUSIONS}

The lived experiences of workers dislocated because of globalized import competition from the Navistar engine plant and foundry who completed an AMTP through TAA reflected a general dissatisfaction with the processes, services and programs, and outcomes associated with TAA. Survey and focus group results indicate these workers found TAA services and processes cumbersome and time-consuming and actually had the effect of discouraging their education, training, and self-employment. The consequences of worker dislocation as it relates to TAA experiences are increased frustration and dissatisfaction with the TAA program. A general sense of failure surrounded these workers even though some workers will return to work with reduced wages and benefits. This exploration suggested a serious need for changes in the application, implementation, and administration of TAA policies. Recommendations for TAA policy changes included an increase in training funding from the federal government, a streamlined and simplified in person or online application process with less paperwork and fewer deadlines, a dedicated training program with competent 
instructors, support staff, and up-to-date materials, and an assessment plan to evaluate the effectiveness of the training program.

\section{References}

Addison, J. T., \& Fox, D. A. (1995). Trade and displacement in manufacturing. Monthly Labor Review, 118(4), 58.

The American Recovery and Reinvestment Act of 2009, Pub. L. No. 111-5, § Section 3101, adding section 3002(b)(2)(B) to the Public Health Services Act (PHSA)123 Stat. 115 (2009).

Ashenfelter, O. (1978). Estimating the effect of training programs on earnings. The Review of Economics and Statistics, 60(1), 47-57.

Beneria, L., \& Santiago, L. E. (2001). The impact of industrial relocation on displaced workers: A case study of Cortland, New York. Economic Development Quarterly, 15(1), 78-89. doi: 10.1177/089124240101500107

Bray, T. J. (2002). Security actions during reduction in workforce efforts: What to do when downsizing. Information System Security, 11(1), 11-15.

Bureau of Labor Statistics. (2010a). Displaced Workers Survey. (USDL-10-1174).

Washington, DC: U.S. Department of Labor, Division of Labor Force Statistics. Retrieved from http://www.bls.gov/news.release/pdf/disp.pdf

Bureau of Labor Statistics. (2010b). Displaced Workers Summary. Washington, DC: Department of Labor, Division of Labor Force Statistics. Retrieved from http://www.bls.gov/news.release/disp.nr0.htm

Bureau of Labor Statistics. (2010c). Displaced Workers survey: Table 6. Long-tenured displaced workers by selected characteristics and area of residence in January 2010. Washington, DC: Department of Labor, Division of Labor Force Statistics. Retrieved from http://www.bls.gov/news.release/disp.t06.htm

Bureau of Labor Statistics. (2011). News release: The employment situation-April 2011. Washington DC: Government Printing Office. Retrieved from http://www.bls.gov/news.release/archives/empsit 05062011.pdf

Bureau of Labor Studies. (2011). The employment situation--April 2011. (USDL-110622). Washington, DC: Government Printing Office. Retrieved from http://www.bls.gov/news.release/archives/empsit_05062011.pdf

Casey, M. K., Miller, V. D., \& Johnson, J. R. (1997). Survivors' information seeking following a reduction in workforce. Communication Research, 24(6), 755-781. doi: 10.1177/0093650297024006007

Creswell, J. W. (2009). Research design: Qualitative, quantitative and mixed methods approaches. Los Angeles: Sage. 
Decker, P., \& Corson, W. (1995). International trade and worker displacement: Evaluation of the Trade Adjustment Assistance Program. Industrial and Labor Relations Review, 48(4), 758-774.

Heckman, J. J., LaLonde, R., \& Smith, J. (1999). The economics and econometrics of active labor market programs (Vol. 3A). Amsterdam, North Holland.

Hipple, S. (1997). Worker displacement in an expanding economy. Monthly Labor Review, 120(12), 29-39.

IBJ Staff. (2010, April 28). Navistar finalizes foundry closing, Indiana Business Journal.

Jacobson, L. S., LaLonde, R., \& Sullivan, D. (1993). Is retraining displaced workers a good investment? Kalamazoo, MI: W. E. Upjohn Institute for Employment Research.

Jacobson, L., Lalonde, R. J., \& Sullivan, D. (2005). The impact of community college retraining on older displaced workers: Should we teach old dogs new tricks? Industrial and Labor Relations Review, 58(3), 398-415.

Joint Economic Committee. (2010a). Understanding the economy: Promising signs of recovery in manufacturing. Washington DC: Retrieved from http://www.jec.senate.gov/public/?a=Files.Serve\&File_id=643c47cd-06d7-4b2986bd-a094446f23c2

Joint Economic Committee. (2010b). Understanding the recovery: Promising signs of recovery in manufacturing. Washington DC: U.S. Congress Retrieved from http://www.jec.senate.gov/public/?a=Files.Serve\&File_id=643c47cd-06d7-4b2986bd-a094446f23c2

Kletzer, L. G. (1998). Job displacement. The Journal of Economic Perspectives, 12(1), 115-136.

Knapp, T., \& Harms, J. (2002). When the screen goes blank: A television plant closing and its impacts on workers. The Sociological Quarterly, 43(4), 607-626.

Koppel, R., \& Hoffman, A. (1996). Dislocation policies in the USA: What should we be doing? Annals of the American Academy of Political and Social Science, 544, 111126.

LaLonde, R. (2003). Employment and training programs in Means-Tested Transfer Programs in the U.S. Chicago: University of Chicago Press for the National Bureau of Economic Research.

Leigh, D. (1995). Assisting workers displaced by structural change. Kalamazoo, MI: W.E. Upjohn Institute for Employment Research.

McLaughlin, K. (2009, January 28). Union says Navistar foundry closing a surprise. Indiana Business Journal.

Olson, S. (2011, July 6). Navistar seeks more tax breaks after old deal failed, Indiana Business Journal. Retrieved from http://www.ibj.com/article/print?articleId=28121 
Todd, M. (2011). PurePower Technologies, LLC officially opens today in former ICC Foundry. News Release. Indianapolis, IN: Develop Indy. Retrieved from www.developindy.com

Working for America Institute. (2001). Trade Act Programs. Washington, DC: AFL-CIO. Retrieved from http://www.workingforamerica.org/actionbriefs/PDF/tradeact.pdf

\section{Author note:}

Direct correspondence to: Marquita R. Walker, Ph.D., Labor Studies Program, Indiana University School of Social Work, 902 West New York Street, Indianapolis, IN 46202. Email: $\underline{\text { marqwalk@iupui.edu }}$ 